South Asia:Journal of South Asian Studies

\title{
An Aesthetics of Isolation: How Pudumaippittan Gave Pre-Eminence to the Tamil Short Story
}

\section{Preetha Mani}

To cite this article: Preetha Mani (2020): An Aesthetics of Isolation: How Pudumaippittan Gave Pre-Eminence to the Tamil Short Story, South Asia: Journal of South Asian Studies, DOI: 10.1080/00856401.2020.1799138

To link to this article: https://doi.org/10.1080/00856401.2020.1799138

\section{Published online: 13 Sep 2020.}

Submit your article to this journal $\sqsubset$

Q View related articles $₫$

View Crossmark data $\asymp$ 


\title{
An Aesthetics of Isolation: How Pudumaippittan Gave Pre-Eminence to the Tamil Short Story
}

\author{
Preetha Mani \\ Department of African, Middle Eastern and South Asian Languages and Program in Comparative \\ Literature, Rutgers University, New Brunswick, NJ, USA
}

\begin{abstract}
The influential Tamil writer Pudumaippittan turned to the short story to theorise the relationship between literature and society in the late colonial era. He used the genre's brevity to compress his portrayals of well-known female types-such as widows, prostitutes and goodwives-into singular emotional events. This enabled Pudumaippittan to evoke the wider debates about tradition and modernity that these female types commonly represented without affirming the social reformist positions to which they were linked. Through the short story, Pudumaippittan dislodged his portrayals of the Indian woman from existing gender norms, prompting a shift from social realism to modernist realism within the Tamil literary sphere.
\end{abstract}

\section{KEYWORDS}

Character type; emotion; genre; Indian woman; modernism; novel; short story; social realism; Tamil literature; Tamil nationalism

\section{A genre of truth}

The short story epitomised the deepest emotional experiences of the individual, concisely conveying life's profound truths. This at least was the conception of the genre that Chockalingam Vrithachalam 'Pudumaippittan' (1906-1948)-considered the doyen of the Tamil short story-put forth in the late colonial era. ${ }^{1}$ Pudumaippittan highlighted the short story for its capacity to inspire individual reflection and social transformation.

Certainly, his position was pragmatic. As a committed fiction writer, editor and journalist, Pudumaippittan recognised how journals could create new readerships. He also understood the centrality of the short story within the journal medium. The short story sold magazines. Ordinary and accessible, this genre had the unique ability to

CONTACT Preetha Mani preetha.mani@rutgers.edu

1. For overviews of Pudumaippittan's life and some of his works, see Lakshmi Holmström, 'Making It New: Pudumaippittan and the Tamil Short Story, 1934-1948', in Lakshmi Holmström (ed.), Pudumaippittan: Fictions (New Delhi: Katha, 2002), pp. 230-51; A.R. Venkatachalapathy, In Those Days There Was No Coffee: Writings in Cultural History (New Delhi: Yoda Press, 2006), pp. 73-85; L. Bychihina, 'Social Realism in Putumaippittan's Short Stories', in Journal of the Institute of Asian Studies, Vol. 3, no. 1 (1985), pp. 147-55; E. Visswanathan, 'Puthumaippiththan's Contribution to Modern Tamil Literature', in Second International Tamil Conference Seminar (Madras: International Association of Tamil Research, 1968), pp. 122-9; and T.M.C. Rangunathan, Putumaippittan Varalāru (Pudumaippittan: A Biography), A.R. Venkatachalapathy (ed.) (Chennai: Kalachuvadu, 2015 [1951]). 
reach audiences across class and caste barriers, providing readers with important insights into common issues and mundane experiences. ${ }^{2}$

Pragmatic reasons may have led Pudumaippittan to focus his energy on the genre. However, it does not explain why he viewed the short story as intimately connected to 'life's truths'. Did the short story have special access to truth? Were the truths it offered distinct from the insights that emerged in other literary forms? Did the short story address the dynamics of the late colonial Tamil context more accurately than other genres, or did it reveal these dynamics in a different light? What, in short, was the social function of the short story?

This essay explores how the short story became a principal genre through which Pudumaippittan theorised the relationship between literature and society. The short story, I show, allowed him to encapsulate the function of literature in compressed form. Prolific across multiple genres, Pudumaippittan developed the short story in conversation with other forms-especially the novel-to make a case for the short story's distinguished position within the Tamil literary field. The short story, he argued, most effectively articulated his vision for how the Tamil community should evolve as Indian Independence became more possible.

In particular, Pudumaippittan used the genre to reconsider popular representations of the Indian woman-a figure highly charged in nationalist debates about community identity. The Indian woman had already become a contested site in the battle between tradition and modernity in nineteenth-century Indian novels. ${ }^{3}$ Meenakshi Mukherjee has observed that the European novel's typical man-woman relationship could not be easily rendered in early Indian novels because of rigid social structures and restrictive marriage conventions. Instead of individual desire and free will, Indian novels sought to 'reconcile two sets of values-one obtained by reading an alien literature and the other available in life'. ${ }^{4}$ Widows, prostitutes, virgins and goodwives conveyed social reformist anxieties-surrounding issues such as education, property inheritance, child marriage, widow remarriage, women's reproductive health, and women's rights to adoption and divorce-allowing Indian novelists to explore the national and regional identities that these types collectively represented. The suffering female figure was a constitutive component of colonial-era Tamil literature and featured prominently in Pudumaippittan's short stories.

This essay argues that the brevity of the short story enabled Pudumaippittan's depictions of the Indian woman to evoke debates about tradition and modernity without embodying the social reformist positions that this figure represented in contemporary novels and poetry. Counter to both the novel's protracted descriptions of character and setting, and poetry's lyrical emphasis on spirituality and desire, the short story compressed colonial-era female types into singular emotional events. Using thumbnail

2. See, for example, Pudumaippittan, 'Kataika! (Short Stories)', in A.R. Venkatachalapathy (ed.), Putumaipittan Kațturaikal (Pudumaippittan's Essays) (Chennai: Kalachuvadu, 2002 [1934]), pp. 112-4.

3. For further discussion, see, for example, Sisir Kumar Das, A History of Indian Literature, 1911-1956: Struggle for Freedom: Triumph and Tragedy (New Delhi: Sahitya Akademi, 1995); and Rajul Sogani, The Hindu Widow in Indian Literature (New Delhi: Oxford University Press, 2002), pp. xiv-xvii.

4. Meenakshi Mukherjee, Realism and Reality: The Novel and Society in India (Delhi: Oxford University Press, 1985), p. 7. See also Meenakshi Mukherjee, 'Introduction', in Meenakshi Mukherjee (ed.), Early Novels in India (New Delhi: Sahitya Akademi, 2002), pp. xiv-xvii. 
sketches of female characters demanded by the form, Pudumaippittan's short stories articulated 'truth' through emotional insight, rather than novelistic didacticism or poetic ecstasy. The formal constraints of the short story dislodged Pudumaippittan's female characters from the conventional gender norms with which they were associated, allowing these figures to express Pudumaippittan's understandings of truth through affect and tone. At the same time, his representations of gender pushed back against the generic requirements of the short story, prompting a shift in colonial-era Tamil fiction from a social realist concern with social reform to a modernist emphasis on individual turmoil. ${ }^{5}$

The first section of the essay shows how Pudumaippittan theorised the function of literature based on his distinct aesthetic tradition and socio-political context. He elaborated a notion of disillusion (nampikai varatci) - which he viewed as necessary for the development of the self-to dissociate literature from ideological debates surrounding language, culture and marriage in colonial Tamil Nadu. The following section illustrates how the short story genre uniquely expressed this understanding of literary purpose by focusing on female characters whose traits had to be presumed based on already recognisable female types, rather than extended character development. This focus allowed Pudumaippittan to unmoor his portrayals of the Indian woman from existing gender roles, thereby dissolving the tradition-bound notions of Tamil community that this figure represented. In the final sections of the essay, I trace this unmooring through Pudumaippittan's short stories, demonstrating that the Tamil short story gained literary import through the repeated citation of locally circulating representations of the Indian woman.

\section{An aesthetics of isolation}

Pudumaippittan located emotional truth at the heart of the literary endeavour. Unarcci (emotion, sentiment, sensibility), wrote Pudumaippittan, was literature's 'life force' (jīvanāti), the most basic element underlying its form (amaippu) and creative power. ${ }^{6}$ Emotion was, therefore, the hidden truth that literature revealed. In his 1934 essay,

5. It could be argued that strains of modernist individualism may be found in the earlier work of V.V.S. lyer (1881-1925), who is considered the father of the Tamil short story. For example, lyer's first short story collection, Mańkaiyarkkaraciyin Katal Mutaliya Kataikal (Mankaiyarkkaraci's Love and Other Stories), published in 1917, focuses on unrequited or tragic love between men and women, featuring the inner workings and process of self-discovery of the anti-hero. See Richard Kennedy, 'Public Voices, Private Voices: Manikkoti, Nationalism, and the Development of the Tamil Short Story, 1914-1947', unpublished PhD dissertation, University of California, USA, 1980, pp. 65-94. However, I would also add that the social realist novel remained the pre-eminent form in modern Tamil literature until the concerted efforts of Pudumaippittan and some of his contemporaries to develop the short story during the 1930s. Their work on the short story produced an unprecedented literary preference for the aesthetic exploration of individual turmoil rather than the overtly social reformist agendas advanced in social realist fiction. For discussion of the early Tamil novel, see Sascha Ebeling, Colonizing the Realm of Words: The Transformation of Tamil Literature in Nineteenth-Century South India (Albany: State University of New York Press, 2010), pp. 205-46. For discussion of the rise of popular novels in Tamil, see A.R. Venkatachalapathy, The Province of the Book: Scholars, Scribes, and Scribblers in Colonial Tamilnadu (Ranikhet: Permanent Black, 2012), pp. 76-98. For discussion of the development of the short story in modern Tamil, see P.G. Sundararajan and Cho. Sivapathasundaram, Tamilil Cirukatai: Varalarum Valarcciyum (The Tamil Short Story: History and Development) (Chennai: Crea, 1989).

6. Pudumaippittan, 'Ilakkiyattin Uțpirivuka! (Literary Genres)', in A.R. Venkatachalapathy (ed.), Putumaippittan Kațturaika! (Pudumaippittan's Essays) (Chennai: Kalachuvadu, 2002 [1934]), pp. 122-4. 
'Ilakkiyattin Irakaciyam (The Secret of Literature)', Pudumaippittan elaborated the interconnectedness of literature and emotion:

What is the place of literature in life (valkkai)?... Literature is the elaboration (virivu) of the self (ullam), the awakening (elucci) of the self, its blossoming (malarcci). A writer examines life with all its complexities and problems (cikkalkal), subtleties (nunukkam), and twists (pimalkal). These produce an emotion (unarcci) deep within him. Literature is the very thing that governs over that stream of emotion (unarcci). It could be the name of a flower that [a writer] doesn't know or a detested political scheme or the severity of human cruelty that catches his attention. No matter. As soon as he notices some particular aspect of life, his heart and mind become troubled. Literature is the representation of this arousal of emotion (calanam).... The pulse of literature is emotion (unarcci) .... The sheer truth (unmai) of emotion leads to a new consciousness (vilippu); [this] truth itself is the secret (rakaciyam) of life. ${ }^{7}$

Arising out of the writer's everyday life, emotion inspired creative production. Fiction transferred writers' own emotional experiences to readers, kindling a transformation of selfhood within them. In Pudumaippittan's view, unarcci enabled readers to develop heightened aesthetic sensibilities for encountering the world in new, unconventional ways. Literature was the very truth of life, the primary basis of human knowledge and community belonging.

Pudumaippittan furthermore maintained that unarcci could only emerge in a state of tanimai-individual isolation or loneliness. In a 1946 essay tracing man's social development, he meditated on the relationship between the individual and society, pointing out a contradiction between them: 'Man precedes society ... the individual (tanimanitan) who tries to see the truth (unmai) is an exception; he is life's sacrificial lamb'. He viewed tradition and religion as narrow and 'society (camūkam) [as] a constraint to the gathering of men'. ${ }^{8}$ In a 1934 essay, Pudumaippittan argued against the popular understanding that unity required a consensus around social issues. ${ }^{9}$ Rather, he believed that isolation was necessary to discover new truths. In this formulation, writers were perhaps the loneliest individuals of all. They alone accessed the emptiness (veruppu) of everyday modern experience and saw 'the truths of the world and secrets of life in a different light'. ${ }^{10}$ The writer's eyes-according to Pudumaippittan-were the very 'eyes of emotion'.11

In Pudumaippittan's view, tanimai was a thoroughly literary sentiment, and the work of the twelfth-century Tamil poet, Kamban, provided the original example. Analysing Kamban's work, Pudumaippittan argued that the poet carefully 'create[d] a web of emotion' through descriptions of a heroine's torment during the sleepless nights she spent awaiting her lover. Kamban's language, style and imagery awakened the

7. Pudumaippittan, 'Ilakkiyattin Irakaciyam (The Secret of Literature)', in A.R. Venkatachalapathy (ed.), Putumaippittan Kațturaika! (Pudumaippittan's Essays) (Chennai: Kalachuvadu, 2002 [1934]), pp. 118-9. All translations in this essay are mine.

8. Pudumaippittan, 'Uńka! Katai (Your Story)', in A.R. Venkatachalapathy (ed.), Putumaippittan Kațuraika! (Pudumaippittan's Essays) (Chennai: Kalachuvadu, 2002 [1946]), pp. 223-4.

9. Pudumaippittan, 'Cima Vișayam (A Small Matter)', in A.R. Venkatachalapathy (ed.), Putumaippittan Katturaika! (Pudumaippittan's Essays) (Chennai: Kalachuvadu, 2002 [1934]), p. 109.

10. Pudumaippittan, 'Kataikal', p. 114.

11. Pudumaippittan, 'Unarcci Vékamum Națai Nayamum (The Rush of Emotions and the Subtlety of Style)', in A.R. Venkatachalapathy (ed.), Putumaippittan Katțuraika! (Pudumaippittan's Essays) (Chennai: Kalachuvadu, 2002 [1934]), p. 129. 
young woman's feelings of desolation in readers. Whether by Kamban, Milton or modern writers in Tamil (among other languages), authentic literature expressed such loneliness. For Pudumaippittan, the fundamental purpose of literature was to create the unarcci (feeling) of tanimai (isolation) through which readers could develop an aesthetic sense of truth.

Tanimai belonged to a world-view that both Lakshmi Holmström and A.R. Venkatachalapathy have identified as Pudumaippittan's nampikai varatci (a drying up of hope or belief), the principal concept guiding his writing. Often translated as pessimism, Holmström elaborates that nampikai varatci 'can also mean skepticism or agnosticism, a this-worldly and questioning position in [Pudumaippittan's] exploration of myths, beliefs and practices'. ${ }^{2}$ Venkatachalapathy further notes that 'while [Pudumaippittan] is deeply, in fact, violently critical of the existing social order, he also doubts every emancipatory project'. ${ }^{13}$ Alongside these understandings, I would emphasise another dimension of Pudumaippittan's literary approach-the profound disillusionment with existing norms and beliefs in his writing, particularly those regarding interpersonal relationships. As I demonstrate below, understanding nampikai varatci as a sense of disenchantment with contemporary social reformist framings of chastity, love and marriage enables us to see how Pudumaippittan's short stories recast prevailing gender norms, grounding them in a literary-rather than social or politicalsensibility.

Pudumaippittan himself coined the phrase to distance himself from the gatekeepers of Tamil literature who dictated which topics were appropriate to literary expression. In a 1942 essay discussing his own relationship to his writing, Pudumaippittan wrote:

Isn't literature supposed to awaken our mental astuteness (maña avacam)?... It's nothing but an outright contradiction of experience to... encounter people like Raman the store-clerk, Sitammal the cinema actress, and Brahmanayakam the ever-bargainer and never give their lives any place [in literature] .... There is nothing inferior in writing about the practices and affairs of daily life.... In literature, artistry lies precisely in the pulses of life .... But, we might ask whether a general drying up of hope or belief (potuttanmai nampikai varațci) in my stories gives legitimacy to a literature focused on unfavorable human characteristics? It is not about the 'poisonous' nature of contrariness, despite what the mature-minded folks who believe this say. ${ }^{14}$

In this passage-and throughout the essay-Pudumaippittan expressed frustration with his contemporaries, many of whom called for the censorship of 'obscene' literary depictions of underworld characters. He also responded to egocentric critics who called his expressions of disillusionment harmful, implying that their criticisms were personal, rather than substantive critiques of his literary project. Pudumaippittan posed the literary worth of nampikai varatci as an ironic rhetorical question, concluding that the very madness (pittam) of his work comprised its creativity and originality. This act was a deliberate play on Pudumaippittan's pseudonym, which meant 'one who is mad or crazy (pittan) for the new (putumai)'.

12. Holmström (ed.), Pudumaippittan, p. 246.

13. Venkatachalapathy, In Those Days There Was No Coffee, p. 76.

14. Pudumaippittan, 'En Kataikalum Nannum (My Stories and I)', in A.R. Venkatachalapathy (ed.), Putumaippittan Kațturaika! (Pudumaippittan's Essays) (Chennai: Kalachuvadu, 2002 [1942]), pp. 177-8. 
Who were the critics to whom Pudumaippittan was responding? He left them unnamed in the essay cited above. In other pieces, however, Pudumaippittan targeted many individuals against whom he defined his work: 'popular' writers producing entertainment-oriented fiction; activists focused on cleansing Tamil of Sanskrit and English influences; social reformers using literature to convey moral lessons; and scholars arguing against deviations from traditional Tamil literary conventions and themes. ${ }^{15}$ In the preface to his 1943 short story collection, Pudumaippittan proclaimed that his stories were meant neither to teach lessons, nor to envision future realities. ${ }^{16}$ Elsewhere, he joked about the nonchalance with which he produced his best-known stories, conjuring them immediately upon request or in response to a friendly challenge. ${ }^{17}$ Through such remarks, Pudumaippittan dissociated his writing from pedagogic or moralistic projects. He claimed madness as a mantle, rejecting predominant Tamil literary methods and cultural and political ideologies.

Despite championing the depiction of quotidian characters and affairs, Pudumaippittan neither endorsed literary realism, nor rejected it. He used poetry as a proxy for all literature to distinguish between inner and outer reality: 'Poetry is truth born of man's emotions (unarcci).... Whether man's inner self (ullam) is part of the yatärtta (realistic) world, or separate from it, is anyone's guess. [Truth] is expressed through the experience of inner life, in the grip of the rush of emotions. That is what poetry is'. ${ }^{18}$ Glossing the Tamil word 'yatärtta' with the English word 'realistic', he singled out the European-influenced realist trend in Tamil literature, which he sought to dismantle by emphasising emotion. In Pudumaippittan's view, each writer's unique inner experience created their writerly style (natai). To demonstrate this point, Pudumaippittan engaged in literary experiments with fellow writers, who compared the differences between short stories they wrote about the same event. ${ }^{19}$ Each individual's distinct creative energy meant that no two writers could narrate the same experience in the same way. A writer's depiction of reality could thus be truthful, despite diverging from external circumstances.

Pudumaippittan also eschewed commitment to idealism, exalting the lonely individual who stood apart from society, unfettered by its constraints. Rather than viewing literature as an avenue for addressing social reformist questions, Pudumaippittan denied literature any connection to political squabbles. He argued-with other writers who converged around the little magazine, Manikkot $i$ - that literature provided intuitive insight into the enigmatic nature of life. ${ }^{20}$ Therefore, literature was built upon-yet also elevated

15. For more on Pudumaippittan's positions on literary and popular writing and Tamil scholarship and language politics, see Preetha Mani, 'Literary and Popular Fiction in Late Colonial Tamil Nadu', in Bodhisattva Chattopadhyay, Aakriti Mandhwani and Anwesha Maity (eds), Indian Genre Fictions: Pasts and Future Histories (London: Routledge, 2019), pp. 17-37.

16. Pudumaippittan, 'Eccarikkai! (Warning!)', in A.R. Venkatachalapathy (ed.), Putumaippittan Kataika! (The Complete Short Stories of Pudumaippittan) (Chennai: Kalachuvadu, 2000 [1943]), p. 779.

17. Pudumaippittan, 'En Kataika! Nānum'.

18. Pudumaippittan, 'Unarcci Vekamum Națai Nayamum', p. 128.

19. For example, Pudumaippittan and B.S. Ramaiah-who worked for the journal Manikkoti-each decided to create a short story about a young woman they encountered together on a street corner in a remote Madras neighbourhood. Their short stories represented two different-yet 'true'-depictions of everyday reality. See Sundararajan and Sivapathasundaram, Tamilil Cirukatai, pp. 184-6.

20. Pudumaippittan's short story, 'Cirpiyin Narakam', published in Manikkotii in 1935, offers one example of this argument. Pudumaippittan, 'Cirpiyin Narakam (The Sculptor's Hell)', in A.R. Venkatachalapathy (ed.), 
above-everyday experience. It articulated the truth of solitude, suffering and despair by giving form to the imaginative worlds produced by these experiences.

Pudumaippittan advanced a literary approach of nampikai varatci (disillusionment) in the context of widespread debates on Tamil language and identity, marriage and conjugality, and the national struggle for independence. He opposed Tamil ethnolinguistic nationalism and its call for a return to the unadulterated Tamil past. He was also at odds with Indian nationalist and Tamil Self-Respect politics, which produced contrasting understandings of heterosexual relationships. The former focused on marriage reform to modernise the nation, while the latter focused on intercaste marriage as a means of promoting social equality. ${ }^{21} \mathrm{~A}$ newly-emerging genre of popular Tamil fiction-which depicted arranged marriage through the lens of family romance and drama-provided an additional counterpoint to Pudumaippittan's work. All these views, his philosophy of nampikai varatci contended, produced overwrought ideals. By contrast, Pudumaippittan viewed Kamban's work as an expression of tanmai (loneliness and isolation) - an emotional state which, until then, had always connoted misery in Tamil literature-and placed the poet at the head of a literary lineage that included both Tamil and Western writers. These interpretations were meant to shock. ${ }^{22}$ His world-view of disillusion implored Tamil readers to connect through shared emotion and aesthetic enlightenment, rather than communal values, traditions or ideals.

\section{Paradigmatic titles and overdetermined types}

Pudumaippittan considered the short story to be an exceptional medium for disclosing literary truth because of its narrowed thematic focus and compact portrayals of character. The short story's brevity enabled the genre to provide readers with unencumbered access to emotional insight. 'The short story is a window on life', wrote Pudumaippittan in a 1935 piece on the short story, succinctly capturing this understanding. ${ }^{23}$ The short story offered a carefully chosen and partial view, one that required whittling down plot and sifting out unnecessary description. Its ambitions were of linguistic precision and affective depth, not thematic scope. It possessed a singular artistic unity, which was structured around emotion and event. The short story was a tightly-knit genre, its totality based on the strength of its focus rather than its expansiveness or heteroglossia. ${ }^{24}$

Pudumaippittan Kataika! (The Short Stories of Pudumaippittan) (Chennai: Kalachuvadu Pathippakam, 2000 [1935]), pp. 325-30.).

21. For more on these debates, see Mytheli Sreenivas, Wives, Widows, Concubines: The Conjugal Family Ideal in Colonial India (Bloomington: Indiana University Press, 2008).

22. I am grateful to George Hart for our discussions of representations of tanmai in premodern Tamil literature. He offered me great insight into how jolting Pudumaippittan's theorisations of loneliness and isolation must have been to his contemporary Tamil readers with a strong sense of Tamil community.

23. Pudumaippittan, 'Cirukatai (The Short Story)', in A.R. Venkatachalapathy (ed.), Putumaippittan Kațturaika! (Pudumaippittan's Essays) (Chennai: Kalachuvadu, 2002 [1935]), p. 142. Pudumaippittan's was the first in a series of essays by various writers published in the influential little magazine, Manikkoți. Beginning in 1935, the magazine defined itself as exclusively focused on short story writing. Pudumaippittan published essays and stories regularly in Manikkoți, and he played a key role in developing its reputation as a harbinger of short story writing and modernism in Tamil. For more on this, see Mani, 'Literary and Popular Fiction in Late Colonial Tamil Nadu'.

24. Bakhtin viewed heteroglossia - the representation of diverse speech genres and social and historical forces-as the pre-eminent feature of the novel. Rather than defining the generic boundaries of the novel, however, 
To make this point, Pudumaippittan juxtaposed the short story and the novel, rather than poetry. Over his lifetime, Pudumaippittan published around one hundred short stories and a novella and also left behind an unfinished novel. However, although he admired several poets-particularly Kamban (c. 1180-1250), Subramania Bharati (1882-1921) and Kanakasabai Subburathinam 'Bharatidasan' (1891-1964) - he wrote very little poetry himself. ${ }^{25}$ I suspect that Pudumaippittan, like other Manikkoți writers, invested primarily in the short story because the genre represented a break from existing Tamil literary traditions. By contrast, the Tamil novel was associated with social reformist agendas, and Tamil poetry was the preferred medium of Dravidian activists.

Pudumaippittan viewed the novel as an aggregate of various characters and events that need not be related. In addition, novelists complemented detailed descriptions of character, plot and setting with their own philosophical or pedagogical explanations. He contended that the short story, by contrast, contained no room for authorial intervention. It provided a more direct means to enlightenment for readers of all backgrounds. Pudumaippittan explained that 'the difference between [the short story] and the novel is that the novel attempts to depict life exactly as it is, with its various difficulties and turbulences. The short story handles one small event or individual matter'. ${ }^{26}$ While the novel was a 'large mirror reflecting life' and meandered through time periods, characters and themes, the short story scrutinised a single instance, expertly omitting all else. ${ }^{27}$ Writers who interjected moralistic lessons into their fiction, Pudumaippittan further argued, failed to create artful stories that encouraged the development of aesthetic sensibilities. ${ }^{28}$

If the novel portrayed life comprehensively, through authorial interpolation, then the short story conveyed human truths through momentary emotional insight. Such insight, moreover, addressed a more fundamental type of reality than did the novel. In Pudumaippittan's view, 'the short story constructs and reveals life's many subtleties through words'. For this reason, he praised a new generation of short story writers who 'stood at the limits of the imagination and folded ideas [into their fiction], which had [otherwise] been trapped within words and refused expression'. ${ }^{29} \mathrm{He}$ contended that reality in the short story was the reality of inner truth, a deeply aesthetic truth that did not necessarily correspond with-to use Pudumaippittan's words-'life exactly as it is'.

Pudumaippittan argued that formal coherence, rather than realistic description, dictated the parameters of the short story genre. He recognised what Charles May has

Bakhtin was interested in documenting the 'novelization' of literary forms, which renewed language and made it dialogic. In his framework, the short story and other modern genres also participated in the novelisation process. Necessarily circumscribed, the short story does not have the capacity for the extensive representation of heteroglossia that the novel does. Nonetheless, as I will demonstrate below, the short story epitomises the parody and irony so central to novelistic discourses. Pudumaippittan's short stories are full of the parodic stylisation that Bakhtin associated with the novel. Parody, I argue, is an integral element of the short story's citational structure. See Mikhail Bakhtin, The Dialogic Imagination: Four Essays, Caryl Emerson and Michael Holquist (trans.) (Austin: University of Texas Press, 1981).

25. For Pudumaippittan's collected poetry, see Pudumaippittan, Cellum Vali Iruttu: Putumaippittan Kavitaika! (The Path I Travel is Dark: Pudumaippittan's Poems) (Chennai: Pudhumaippiththan Pathippagam, 2002).

26. Pudumaippittan, 'Kataika!', p. 112.

27. Pudumaippittan, 'Cirukatai', pp. 142-3.

28. Pudumaippittan, 'Cirukatai: Marumalarccik Kalam (The Short Story: The Era of Renaissance)', in A.R. Venkatachalapathy (ed.), Putumaippittan Katțuraika! (Pudumaippittan's Essays) (Chennai: Kalachuvadu, 2002 [1946]), p. 235.

29. Ibid., pp. $237-8$. 
described as the short story's structure of pattern and repetition, which constructs the 'immaterial reality of the inner world' and highlights 'an experience... directly and emotionally created and encountered'. ${ }^{30}$ May traces the development of the short story in the West and locates the genre's pattern and repetition in writers' uses of language and symbolism. The recurrence of words and images within a story imparts it with ineffable, metaphoric meaning. ${ }^{31}$ In Pudumaippittan's case, patterns of words and symbols sometimes operated within individual stories, but more often, these patterns were reiterations of words and images from texts outside of them. The repetition was in essence a citation of representations already in circulation, particularly those related to the ideal Indian woman. Pudumaippittan's citation of over-determined female types, as I demonstrate below, made the emergence of emotional insight in his stories possible.

Formally, these citations could be found in the reverberations between Pudumaippittan's short story titles and his female characters. In the novel, the title is what Gerard Genette has called a 'paratext'. Separated from the novel's content by a page break, the title imposes thematic unity from beyond, designating the novel's primary subject matter and articulating the author's, translator's, editor's or publisher's own interpretation of the work. ${ }^{32}$ Short story titles work differently. Published in journals and magazines, they-like poems or essays-adjoin the text, function as the first line of the text, and relay meaning through their constant conversation with the narrative. ${ }^{33}$ Many of Pudumaippittan's short story titles referenced well-known objects, figures or images. They served as launching points for shaping alternative perspectives on his stories. They brought signs already burdened with meaning into the stories to explore, parody or critique those meanings, changing them as a result.

Pudumaippittan's short story oeuvre is full of paradigmatic titles. Take, for instance, stories such as 'Pomakaram (The Golden City)', 'Akalyai (Ahalya)', 'Oppantam (The Contract)', 'Āṇmai (Manliness)', 'Vali (A Way Out)' and 'Kōpālayyañkārin Manaivi (Gopal Iyengar's Wife)'. ${ }^{34}$ Though not all of these titles are evocative of female types per se, each employs a stereotype or motif intimately linked with contemporary Tamil conceptions of gender. For example, Pudumaippittan's title, 'Ponnakaram', refers to the city of Vanci where Kannaki-the unjustly wronged heroine of the ancient Tamil epic Cilappatikäram-was honoured as a goddess and presiding deity. To a Tamil reader, Pudumaippittan's ironic use of this title becomes evident immediately upon discovering the story's plot. 'Pomakaram' follows Ammalu, the wife of a useless drunkard,

30. Charles May, 'I Am Your Brother': Short Story Studies (North Charleston, SC: CreatSpace Independent Publishing, 2013), p. 53.

31. Charles May, 'Reality in the Modern Short Story', in Style, Vol. 27, no. 3 (1993), pp. 369-79.

32. Gerard Genette, Paratexts: Thresholds of Interpretation, Jane E. Lewin (trans.) (Cambridge: Cambridge University Press, 1997 [1987]), pp. 55-103.

33. It could be argued that short story titles function similarly to chapter titles or section headings, which Genette considered to be kinds of paratext. However, Genette was primarily interested in the book form and argued that paratexts work together with the main text to construct the impression of a comprehensive whole. I would suggest that short stories-as well as other genres-published in journals and magazines operate differently in that they can also be (and often are) read separately, rather than as components of a larger whole. For this reason, short story titles-like the titles of poems, essays and columns-are more closely linked to the content they announce than the titles of books or chapters and sections within books.

34. These stories are collected in A.R. Venkatachalapathy (ed.), Putumaippittan Kataikal (The Complete Short Stories of Pudumaippittan) (Chennai: Kalachuvadu, 2000). 
who slips off in the darkness to have sex with a stranger to earn a few rupees for her family. "'Chastity, chastity!” you keep saying. Well, this, sir, is the golden city!' the narrator concludes. ${ }^{35}$ Contrasting Ammalu's transgression of wifely chastity with the ancient heroine Kannaki's virtuous devotion to her husband, Pudumaippittan's story addresses the sexual anxieties associated with city living and exposes the impracticalities of upholding traditional expectations of wifely behaviour in such a setting. The story's title and its depictions of Ammalu work with-as well as against-one another to topple the utopian ideals of gendered propriety prevalent in the rapidly urbanising Tamil context of Pudumaippittan's time.

Like 'Ponnakaram', Pudumaippittan's 'Akalyai' (ŪIIyan, 1934)—which I discuss further below-contrasts ancient and modern ideals of gender through an unusual account of the despair and isolation felt by the ideal wife Ahalya (Ahalyā), whose story is recounted in the ancient epic, the Rammanana. At odds with social reformist positions on marriage, Pudumaippittan's 'Oppantam' (Manikkoti i, 1934) compares the two bestknown types of male-female contracts-the dowry contract and the business 'contract' arranged between philanderers and prostitutes. 'Anmai' (Manikkoți, 1934) exposes the character weakness of a young man and the mental derangement he causes his lover as the two try to break away from the conventions of the arranged marriage. ' $V a l i$ ' (Manikkoti $i$ 1935) delves into a widow's despair as she contemplates suicide now that the practice of sati (widow immolation) has been banned. And, 'Kōpālayyanikārin Manaivi' (Manikkoti, 1934) portrays a Brahman man's failed efforts to defy caste conventions by marrying a low-caste woman. Pudumaippittan begins the story with a note referencing the characters Gopal Iyengar and Meenakshi-who were featured in his literary predecessor Bharati's well-known novel, Cantirikaiyin Katai (The Story of Chandrika) - and fashions his portrayal as a satirical rewriting of this iconic intercaste couple. The titles of all of these stories recall tropes and symbols that carry recognisably gendered connotations within the Tamil context and shrewdly deploy them to destabilise existing social reformist paradigms.

Pudumaippittan's female short story characters are brilliant in their allusion to already circulating types, rather than in their precise or extensive character development. These characters are, for this reason, neither flat nor round. In his 1927 Aspects of the Novel, E.M. Forster elaborated on the concepts of flatness and roundness in a way that has now become commonplace. He designated flat characters as 'types' or 'caricatures' which were 'constructed round a single idea or quality'. ${ }^{36}$ They are familiar and predictable, whereas round characters are more nuanced and appear to extend from the pages of a novel into the reader's own reality. ${ }^{37}$ Both flat and round characters were-according to Forster-principal features of a successful novel. Their delineation helps to meet the formal requirements of the genre-such as plot, theme and moodas well as to satisfy readers' tastes.

Unlike the novel, the formal aspects of the short story hinge upon brevity, a property that does not permit flat and round characters to fully surface. Since short story

35. Pudumaippittan, 'Ponnakaram (The Golden City)', in A.R. Venkatachalapathy (ed.), Putumaippittan Kataika! (The Complete Short Stories of Pudumaippittan) (Chennai: Kalachuvadu, 2000 [1934]), p. 68.

36. E.M. Forster, Aspects of the Novel (New York: Harcourt, Brace, \& Co., 1927), pp. 103-4.

37. Ibid., p. 118. 
characters are circumscribed within a single moment or event, they remain at a tangent to the chronological rootedness that the novel confers on its protagonists. Georg Lukács argued that the novel's development of characters in historical time undergirds the 'typicality' of literary types - their ability to synthesise idiosyncratic individual experience with broader historical processes to reveal the social whole. For this reason, Lukács was pessimistic about the short story. He believed that it lacked the same utopian potential of the novel which could reconcile individual interiority with external reality. The short story, for Lukács, was not properly historical. ${ }^{38}$ Yet, Pudumaippittan's short stories demonstrate that the historicity of the genre lay in its citation of recognised character types-its ability to call types into existence without lending them narrative space. This is what his short story titles enabled him to accomplish.

\section{Citations of sympathy}

The citation of female types allowed Pudumaippittan's stories to prioritise affect. Citation replaced protracted descriptions of character with key familiar descriptors, allowing his female characters to quickly and concisely evoke current understandings of Indian womanhood. In this way, citation cleared a path for Pudumaippittan's female characters to facilitate the unfolding of the short story's emotional event.

Female short story characters alluded to existing feminine ideals, which were associated with women's suffering. Dipesh Chakrabarty has argued that-beginning in the nineteenth century-the widow became the model subject of suffering. Produced by individual and collective experiences, this figure embodied the modern selfs struggle to negotiate individual desire within traditional kinship structures. Furthermore, 'to build an archive of the widow's interiority, to see her self as deep and stratified ... required the development of a set of observational techniques for studying and describing human psychology. This was a role performed primarily by the novel'. ${ }^{39}$ By transforming the widow's heterosexual romantic desires into a transcendent spiritual love, the novel trained readers to enter into what Toral Gajarawala has called the 'circle of readerly sympathy'. ${ }^{40}$ The novel's sublimation of feminine desire allowed readers to feel compassion for female characters. Pudumaippittan's short stories reveal a fundamental difference between the novel and the short story. The short story referenced female suffering-rather than chronicling it-stirring readerly sympathy without sublimating feminine desire. If the aim of literature was to generate human connection-as Pudumaippittan maintained-then the short story's citation of female suffering was the most direct means for achieving this end.

38. See Georg Lukács, The Theory of the Novel: A Historico-Philosophical Essay on the Forms of Great Epic Literature, Anna Bostock (trans.) (Boston, MA: MIT Press, 1971 [1920]); and Georg Lukács, The Historical Novel, Hannah Mitchell and Stanley Mitchell (trans.) (Lincoln: University of Nebraska Press, 1962).

39. Dipesh Chakrabarty, Provincializing Europe: Postcolonial Thought and Historical Difference (Princeton, NJ: Princeton University Press, 2000), p. 133.

40. Toral Gajarawala, Untouchable Fictions: Literary Realism and the Crisis of Caste (New York: Fordham University Press, 2013), p. 45. 
Pudumaippittan's two retellings of the Ahalya episode from the ancient epic, the Rámanyana (c. second century CE), illustrate the arc of his experimentation with gender norms. The two Ahalyas are explicit citations of the feminine ideals embodied by Ahalya, the ideal wife of the sage Gautama. In the epic version, when lusty Indra visits her in the dead of night disguised as her husband, Ahalya-though she 'knew it was Indra of the Thousand Eyes'-sleeps with him, 'excited, curious about the king of gods' ${ }^{41}$ Enraged when he discovers what has happened, Gautama curses Ahalya; she will become a stone until King Rama's foot brushes it as he walks past. Many years later, Rama releases Ahalya from the curse and, cleansed of her blemished past, she reunites with her husband.

Pudumaippittan's first retelling of this story, 'Ahalyai (Ahalya)', was published in Manikkoti in 1934, at the beginning of his career. This was the first in a series of Ahalya re-writings, which were part of a wider debate about the relationship of fiction to literary convention and cultural tradition. ${ }^{42}$ The Manikkot $i$ writers' turn to myth was related to their concomitant experiments with narrating 'real life' events. ${ }^{43}$ They believed that re-envisioning their own experiences and exploring canonical stories would challenge the breadth of their creativity and imagination. Pudumaippittan's 'Ahalyai' launched this exercise by imagining the conditions under which Ahalya, who was 'the epitome of womanhood', would fall for another man. ${ }^{44}$

'Ahalyai' drew on several longstanding versions of the Ahalya episode, which revised the Rámáana story to portray Ahalya as an innocent victim of Indra's wiles, rather than a knowing participant. ${ }^{45}$ Pudumaippittan's retelling was unusual, however, because it focused on Ahalya's psychological state. In his story, Ahalya was a devoted, but also desiring wife. One evening she waits patiently by Gautama's side while he finishes his textual recitations:

For a while, Gautama doesn't even notice she's there, he's so engrossed in the text. He laughs with a glance full of tenderness, 'What is it, Ahalya? Getting late? Time to bathe? I'll be there soon. There's only a little more of this text left to read'.

She puts down her basket and gathers his head into her chest. She brushes her lips across his forehead and just stands there. 'See you'. She picks up the basket and walks towards the river. In her heart, a trace of disappointment-if she hadn't had to wait so long, she might have been able to enjoy being with her husband for a little and to take him to the river. She's not angry with him though. ${ }^{46}$

In Pudumaippittan's version, Gautama and Ahalya share a passionate relationship. For Gautama, though, it takes second place to his ascetic duties. Gautama is serious,

41. A.K. Ramanujan, 'Three Hundred Ramayanas: Five Examples and Three Thoughts on Translation', in Vinay Dharwadker (ed.), The Collected Essays of A.K. Ramanujan (New Delhi: Oxford University Press, 1991), p. 135. Ramanujan's translation of this passage is from the Sanskrit poet Valmiki's text.

42. See Das, Struggle for Freedom, p. 134; and Sundararajan and Sivapathasundaram, Tamilil Cirukatai, pp. 185-6, for an overview of some of the Ahalya retellings.

43. Sundararajan and Sivapathasundaram, Tamilil Cirukatai, pp. 184-6.

44. Pudumaippittan, 'Ahalyai (Ahalya)', in A.R. Venkatachalapathy (ed.), Putumaippittan Kataika! (The Complete Short Stories of Pudumaippittan) (Chennai: Kalachuvadu, 2000 [1934]), p. 133.

45. For a summary of the evolution of the Ahalya myth from its earliest appearance in the Rāmāyana, see Renate Söhnen-Thieme, 'The Ahalyā Story through the Ages', in Julia Leslie (ed.), Myth and Mythmaking: Continuous Evolution in the Indian Tradition (New York: Curzon, 1996).

46. Pudumaippittan, 'Ahalyai', p. 132. 
focused, equanimous. Ahalya, conversely, longs to frolic with her husband and savour physical intimacy, though she suppresses these desires.

When Ahalya discovers Indra spying on her as she bathes, she stares him down, then rushes away. Gautama tries to console his distraught wife and puts the incident behind him. Ahalya's mind, however, 'is in turmoil, as if she has committed some great, unacceptable sin'-as if she might not be able to quell her physical response to Indra despite her wifely devotion. ${ }^{47}$ This is an intuition that foreshadows her impending rape. More significantly, it reflects a deep anxiety found in most of the late-colonial era Ahalya retellings-that no matter how disciplined and pure women's minds may be, their bodies cannot be fully controlled.

When Gautama rises for his morning ablutions, Indra sneaks into their bedroom. Ahalya lies dreaming of her husband. Indra looks at the feeble woman, asleep, her clothes disheveled. An animal's lust is fulfilled today. Ahalya doesn't wake from her half-dream state. She embraces Indra thinking it's her husband. In a way, this is the victory of nature ${ }^{48}$ Corporeal desire, the narrator suggests, cannot be ignored or overcome. Gautama emphasises this lesson in his response to Indra's insidious actions:

'Dearest Ahalya, how could your body have become an unfeeling stone at such a moment?' he asks, stroking her hair.

In his mind, tranquility.

A new truth:

'Emotion can turn even a god into an animal. But chastity lies in the purity of the mind. What can a poor woman do if her body becomes polluted in such circumstances?'

Silence.

'Leave Indra!' says Gautama. Even now, the calmness of his mind is clear.

And Ahalya?

The irrevocable, apocalyptic event that had taken place within her stands opposed to her husband's peace. ${ }^{49}$

The story ends with this sombre image of Ahalya's emotional turmoil. The truth of the story is the trauma of rape, not Gautama's rationalisation. Ahalya's distressing personal experience distances her from Gautama. It creates a condition of inner isolation.

Pudumaippittan's second retelling of the Ahalya episode focused more closely on this isolation, revealing it to be an integral component of Ahalya's identity. I read the story as the third in a trilogy of stories featuring spectre-like women, which Pudumaippittan published sequentially in 1943 in the magazine Kalaimakal. In the first, the eponymous Kanchanai appears at the doorstep of a writer and his pregnant wife. She offers her services in exchange for room and board. The writer's wife instantaneously takes pity on her and befriends Kanchanai, but the writer himself cannot shake off the feeling that Kanchanai poses a threat. ${ }^{50}$ Is she a ghost or human? A wife,

47. Ibid., p. 133.

48. Ibid., p. 134.

49. Ibid., p. 135.

50. Pudumaippittan, 'Kañcanai (Kanchanai)', in A.R. Venkatachalapthy (ed.), Putumaippittan Kataika! (The Complete Short Stories of Pudumaippittan) (Chennai: Kalachuvadu, 2000 [1943]), pp. 507-16. 
a widow, a prostitute? Similarly, Chellammal, the eponymous character of the second story, is dead in the opening scene. The rest of the narrative flashes back to her slow deterioration through the eyes of her unobtrusive husband, who structured his entire life around Chellammal's illness. ${ }^{51}$ Chellammal is an empty vessel around which gathers profound sadness and inertia. Both stories leave the question of female identity unanswered, offering Kanchanai and Chellammal as dubious citations of the ideal female type.

The protagonist of the third story in the 1943 trilogy-Pudumaippittan's Ahalyafollows in a similar vein. She interrogates the female type, disputing the feasibility of its existence in contemporary times. Titled 'Cāpa Vimōcanam (Deliverance from the Curse)', the story begins with a caveat: 'For those familiar with the Ramayana, this story may seem incomprehensible, distasteful even. I haven't bothered about this' ${ }^{52}$ At the outset, the story seeks to unsettle readers. Ahalya, incapable of returning to her earlier self, embodies disillusionment with established gender norms. When Rama brings her back to life, she realises she can no longer confidently interact with men. She constantly questions the purity of her intentions and whether her words and actions convey what she wants them to express:

The stone lodged in her heart had not budged. She wished to conduct herself in a way that wouldn't arouse suspicion in others or cause them to purposely stare. Consequently, she forgot how to be natural. Her whole demeanour changed. Everyone around her appeared to be Indras, and fear froze Ahalya's heart. The laughter and playfulness of her earlier days vanished. She rehearsed each word a thousand times, examining it from every angle to make sure it was right before she spoke. She agonised over Gautama's words, too, wondering whether they held some deeper meaning. Life itself became hellish torment. ${ }^{53}$

Crushed by the trauma of Indra's rape, Ahalya is now a ghost of her former self.

Gautama is also plagued by guilt, and he loses his peaceful comportment. 'In his mind, Ahalya moved about free of blemish. He was the unworthy one, he felt. The anger that had incited his fiery curse tainted him instead .... His faith dried up and vanished into nothingness' ${ }^{54}$ Gautama begins to understand the place of emotion in life, but the couple becomes increasingly estranged. They journey together in search of reconciliation, crossing landscapes 'identical to the oppressive drying up of hope (nampikai varatci) within them'. ${ }^{55}$ Despite their efforts, Gautama and Ahalya find that their heterosexual bond-built on the ideal masculine and feminine qualities they once possessed-no longer holds.

Ahalya seeks comfort from Rama's wife, Sita, who serves as a model for the happy marital life she hopes to regain. However, after learning that Sita stepped into fire to prove her chastity to Rama after the demon king Ravana abducted her, Ahalya shudders:

'Did he ask you to do it? Why did you do it?' she asked.

'He asked me, I did it', Sita quietly replied.

51. Pudumaippittan, 'Cellammāl (Chellammal)', in A.R. Venkatachalapathy (ed.), Putumaippittan Kataika! (The Complete Short Stories of Pudumaippittan) (Chennai: Kalachuvadu, 2000 [1943]), pp. 517-34.

52. Pudumaippittan, 'Cäpa Vimōcañam (Deliverance from the Curse)', in A.R. Venkatachalapathy, Putumaippittan Kataika! (The Complete Short Stories of Pudumaippittan) (Chennai: Kalachuvadu, 2000 [1943]), p. 535.

53. Ibid., pp. 538-9.

54. Ibid., pp. 539-40.

55. Ibid., p. 544. 
'He asked you?' Ahalya screamed .... One law for Ahalya, and another for Rama? Was it betrayal? A justice born from the recesses of Gautama's curse?

Both were silent a while. Sita laughed softly, 'Didn't he have to prove it to the world?'

'Isn't it enough to know it within oneself? Can the truth really be proven to the whole world?' asked Ahalya. Words abandoned her. 'Is it only true if you prove it? Even if it doesn't touch your heart? Let it be. What's this world anyway? ${ }^{56}$

Ahalya gives up. If Rama-who once delivered her from her curse-still questioned his own wife's virtue, what change could the future possibly hold? Gautama approaches Ahalya in hopes of conceiving a child, but Ahalya petrifies into stone to ease her heart's burden. It is an ending that confirms Pudumaippittan's literary philosophy of disillusion (nampikai varatci) and its secret truth of isolation (tanimai).

Together, the Ahalya stories suggest the inarticulability of feminine desire, the lack of a place for it anywhere in the world. The irreconcilable schism between Ahalya's mental 'purity' and her physical 'pollution' suggests that feminine desire is, perhaps, the most isolating desire there is. Utterly corporeal, it can never be accepted, fulfilled or overcome. In Ahalya's case, however, to abandon feminine desire is to annihilate the self. Her dilemma symbolises the lonely desperation of the modern individual, whose rich emotional life lies deep in the heart of the short story, but is not yet free in the world beyond.

\section{Formal locations}

Ahalya's loneliness was Pudumaippittan's response to the polarised Tamil landscape that troubled him throughout his writing career. Dutiful, devoted and sacrificing, her character cited the spiritually elevated desires of the ideal feminine type. Withdrawn, doubting and estranged, she also undermined these desires by revealing their unsustainability in contemporary times. She was an affront to Tamil Brahman sentimentswhich valorised Hindu values of kinship and tradition as the basis of national unityas well as to Tamil non-Brahman sentiments-which violently rejected Hindu culture because it oppressed Dravidian identity. Ahalya's repudiation of the heterosexual bond was a rejection of both these prevalent frameworks of sociality. ${ }^{57}$ The female character, in Pudumaippittan's short stories, was a symbol, rather than a type-an emotionally charged metaphor for nampikai varatci, the utter loneliness of human desire. This truth was linked to the specific Tamil ethno-linguistic dynamics of Pudumaippittan's time and place.

Ahalya demonstrates how local social relations were deeply embedded into the form of Pudumaippittan's stories themselves. Fashioned by a dialogue between title and content, this female character shaped the short story's citational structure, which

56. Ibid., p. 547.

57. A.R. Venkatachalapathy recounts that 'C. Rajagopalachari, the self-appointed custodian of Indian (Hindu) culture ... wrote a veiled rejoinder in the form of a re-telling of the Agaligai story from the Ur-text of Valmiki' immediately following Pudumaippittan's publication of 'Capa Vimōcanam'. See Venkatachalapathy, In Those Days There Was No Coffee, p. 81. Rajagopalachari's position on the Ahalya myth represented the Hindu viewpoint of the Indian National Congress - the leading political party across the subcontinent. Pudumaippittan's Ahalya also offered a different position on heterosexual relations than the reformed marriage practices that the Self-Respect Movement advanced, which emphasised equality and free will as opposed to kinship and tradition. 
referenced local discourses of the Indian woman and reworked them into geographically specific emotional insights. The issue was not one of 'compromise between western formal influence ... and local materials', as Franco Moretti has argued in his discussion of the novel's global circulation. ${ }^{58}$ Drawing on a centre-periphery paradigm in which power and influence flow unidirectionally eastward, Moretti views the novel as a primary genre of world literature in the modern era. Formal debt to the European novel-the signature of the 'one-and-unequal' world literary system-makes local and national literatures legible on Moretti's scale, one defined by literary-critical distance from texts. At stake in Pudumaippittan's turn to the short story, by contrast, were questions of political utility and aesthetic exploration-questions shaped by the labour performed by genre in his context, and not its formal borrowings or cultural defects. Pudumaippittan's work on the short story compels us to reconsider the evolution of form from a more located, yet also pluralistic position.

As the female characters of Tamil short stories became increasingly unhinged from existing gender norms, the citational structure of the short story grew increasingly tropological. Characters dissociated from their metaliterary referents and became singularities in their own right. Accordingly, late-colonial era Tamil short story titles gradually transformed from descriptive statements of subject matter into metaliterary commentaries of content. Pudumaippittan's prolific short story career demonstrates this shift, portending new forms of post-colonial Tamil modernist realism which were nascent, bubbling, ready to come.

\section{Disclosure statement}

No potential conflict of interest was reported by the author(s).

\section{Appendix}

\section{Pudumaippittan, 'Ilakkiyattin Irakaciyam (The Secret of Literature) ${ }^{59}$}

\section{Translated from Tamil by Preetha Mani}

Chockalingam Vrithachalam 'Pudumaippittan' (1906-1948)-perhaps still the most widely read Tamil writer today-is credited with revolutionising the Tamil short story and launching a new modernist strain of Tamil literature during the late colonial period. He was a journalist, editor, essayist, short story writer and occasional poet, and he even tried his hand at an (unfinished) novel. Pudumaippittan wrote during the height of the Indian Independence movement, when Tamil ethno-linguistic nationalism weighed heavily on the cultural scene. Yet, as Pudumaippittan's pseudonym-which means 'crazy (pittan) for the new (putumai)'-attempts to express, he was deliberately iconoclastic and eschewed political, aesthetic and religious ideologies of all kinds.

'The Secret of Literature' was published in the first properly 'literary' small magazine in Tamil, Manikkoti, on 28 October 1934, and it exemplifies one of Pudumaippittan's major contributions to the evolving Tamil literary field. This was the emphasis on emotion-what Pudumaippittan called unarcci (emotion, sentiment or sensibility) - that he brought to bear on

58. Franco Moretti, 'Conjectures on World Literature', in New Left Review, no. 1 (2000), p. 58.

59. Pudumaippittan, 'Ilakkiyattin Irakaciyam (The Secret of Literature)', in A.R. Venkatachalapathy (ed.), Putumaippittan Kațuraika! (Pudumaippittan's Essays) (Chennai: Kalachuvadu, 2002 [1934]), pp. 118-9. 
Tamil aesthetic debates of the period. In this short and rather feisty essay, Pudumaippittan employed examples usually linked with religion, while emphasising their aesthetic significance. Explicitly drawing on traditions outside Tamil, he critiqued the Dravidian, Self-Respect and Pure Tamil movements' valorisations of the Tamil religion, language and cultural heritage, which were prominent at the time. Pudumaippittan located the growth of the individual and the transformation of society in literary sentiment. In this way, he placed literature at the very core of modern life.

What is the place of literature in life? There are two types of answers to this. Both are half true. One theory is that literature is a great pastime, an enchanting dream. Another perspective is that literature throws open the secret of existence, demanding that life develop and progress. Historically speaking, it doesn't make sense to conclude that literature is a bewitching but useless dream of men. Literature creates. It gives birth to a new consciousness within people. Take the French Revolution, for example. It's the poet who first ushers in the new maiden of dawn. His vision produces a new society among men.

Now, if you follow the debate to its logical end, it becomes a farce worthy of ridicule. There have been excellent literatures that are contrary to this position and fracture its line of reasoning. If literature were only there to elevate religion, then we would also have to believe that the rose's beauty is only for the sake of the fragrance that can be extracted from it. What religious doctrine does Keats' 'Endymion' promote? Can the trouble that Shaw's entire dramatic corpus takes to display the world compare to a single line of Keats' poem?

There is no more misleading opinion than thinking that literature is a means for 'accumulating desirable things'. Literature is the elaboration of the self, the awakening of the self, its blossoming. A writer examines life with all its complexities and problems, subtleties and twists. These produce an emotion deep within him. Literature is the very thing that governs over that stream of emotion. It could be the name of a flower that a writer does not know or a detested political scheme or the severity of human cruelty that catches his attention. No matter. As soon as he notices some particular aspect of life, his heart and mind become troubled. Literature is the representation of that aroused emotional state.

Kamban's twelfth-century Tamil Ramayana is a captivating dream. A vision of literary perfection. It awakens a new society. However, contending that the greatness of Kamban's Ramayana is based solely on its power to create community is just talk for the sake of conversation and amusement, rather than logically sound. Only those who don't understand the Kamban Ramayana's greatness can say such things.

There's no greater misunderstanding than the idea that the poetry of the ninth-century Shaivite saint Manikkavacar and his Tamil Vaisnava contemporaries emerged for the sake of establishing religion. These poets were immersed in the comprehensive sciences and secrets of life. Their poetry is the very result of these engagements. People may have understood their poetry as religious propaganda in earlier times, but it cannot be said that this poetry emerged simply as propaganda.

Apparently, Napoleon once said, 'I will awaken the city of Paris through Homer's poetry'. There's a truth to this. The pulse of literature is emotion. The doctrines of religion-which do not arise from emotion-weigh life down like boulders. The sheer truth of emotion leads to a new consciousness; truth itself is the secret of literature. 